deliver in the summer. But a serious defection from the treaty, which that of Iraq would be, could nullify even an agreement on strategic arms.

Other arrangements for restricting the spread of advanced military technology, the informal understandings between the major powers on nuclear and rocket technology and the equipment needed for making chemical weapons, are inevitably more leaky, as the past few years have shown. They cannot be a permanent safeguard, but only an impediment. Even so, there seems no ready explanation for the way in which small defence contractors in West Germany and Britain appear to be willing to turn a dishonest penny by selling forbidden technology, and at the same time appear to be privy to enough secret information to realise their ambitions.

What, in these circumstances, can be done? The most urgent need is that China and France, nuclear powers which have chosen not to sign the NPT, should be tempted into the club. It would be splendid if that could be done by September, when the fourth quinquennial review conference of the treaty is due. But that step is neither necessary nor sufficient. French objections, unfashionably gaullist as they are, no longer carry much weight even in France. China will evidently be a harder nut to crack, especially now that events in Beijing a year ago have led to an embargo on the supply of advanced 'conventional' military technology - aircraft and the like. To create the climate in which to win China round to membership, the other nuclear powers may have to follow a self-denying ordinance on the sale of arms of all kinds. That would be no bad thing.

\section{Abortion from a hat}

The British government is making a quick stab at abortion legislation in what may be the worst possible way.

TOwARDs the end of last year, the president of the Royal Society, Sir George Porter, wrote to the London Times to plead that the issue of artificial abortion should not be confused with the issues raised by the Embryo Bill, then beginning its journey through the British Parliament. The hope was that calm consideration of the legislation to regulate research with human embryos would not be prevented by the emotionally charged arguments habitually assembled for and against abortion. There have always been reasons for believing that the hope would be disappointed, while the Embryo Bill, which proposes a 14-day time limit for experiments with embryos, will almost certainly be used as an argument against abortion when the bill becomes law. But now the British government has startled the House of Commons by announcing that it intends to tag onto the Embryo Bill an amendment that would fix the legal time-limit for abortion at 24 weeks rather than the present 28 weeks.
The decision is both mystifying and deplorable. The Embryo Bill is the government's belated attempt to give effect to the Warnock proposals on embryo research, now six years old. There is an urgent need of it. Although opinions differ on some aspects of the bill, the sanctity of the 14-day limit for example, it is the best that is likely to be had from this parliament, which has just over two years at most to run. So why should the government complicate and perhaps even jeopardize the passage of its own legislation by converting that into a trojan horse for the carriage of an amendment of abortion law? Opportunism seems to be the simplest answer.

As the technology of medicine has advanced, the case for reducing the time-limit for abortions from the present 28 weeks has been strengthened. The diagnosis of pregnancy has been simplified and made more accurate, while the survival of early fetuses is more easily assured. Two years ago, the government was attacked for failing to use its powers to assist legislation put forward by Mr David Alton, MP. More recently, it has failed to lift a finger to help through the House of Commons legislation successfully introduced in the House of Lords by Lord Houghton. Until now. By all accounts, the government's intention is to incorporate the essence of Lord Houghton's Bill into its amendment, which is to be debated later in the month.

The case for some such amendment is not negligible, but the course now proposed is unsatisfactory. Its most serious defect is that it allows no time for public discussion. The reason why abortion is a contentious issue is that the available spectrum of opinion is spanned by warring lobbies whose arguments, while cancelling out each other, make all compromises unacceptable. At the extremes are the views that all abortions are acts of murder and that women, uniquely susceptible to pregnancy, have a right individually to choose what happens to their own bodies. But even within the framework of the existing legislation on abortion, much has been done by intelligent medical practice to avoid late terminations. There would be a case for new legislation on the issue only if there were reason to believe that present legislation should be scrapped or if some objective and thorough study of the working of the present system had suggested that a more intelligent compromise than the present could be reached. Neither of those conditions has been met.

So what will be the outcome? The government may mollify some of those who have criticized its inactivity on the Alton bill, but ironically will probably offend a greater number who hold the Houghton measure to be milk and water. (By counting from the supposed time of fertilization, taken as two weeks after the last menstrual period, the Houghton bill reduces the present time limit by only two weeks.) But one thing is certain - the Embryo Bill will be further delayed by the need for another long discussion in the House of Lords. But worse, on yet another contentious issue, the prospect that a more intelligent compromise might be reached after discussion has been buried under a government decree. 